\title{
Origin of calcite in the glacigenic Virttaankangas complex
}

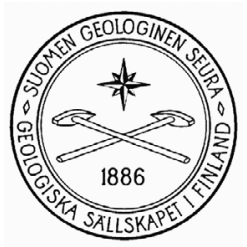

\author{
Nina M. Kortelainen ${ }^{1) *}$, Petri J. Korkeakoski ${ }^{1)}$, Juha A. Karhu ${ }^{2)}$ \\ 1) Geological Survey of Finland, P.O. Box 96, FI-02151 Espoo, Finland \\ 2) Department of Geology, P.O. Box 64, FI-00014 University of Helsinki, Finland
}

\begin{abstract}
Groundwaters of the glacigenic Virttaankangas complex in southern Finland are characterized by high $\mathrm{pH}$ values ranging up to 9.5. These values are significantly higher than those observed in silicate-rich shallow groundwater formations in crystalline bedrock areas. The Virttaankangas sediments were discovered to contain small amounts of fine grained, dispersed calcite, which has a high tendency to increase the $\mathrm{pH}$ of local groundwaters. The primary goal of this study was to determine the mode of occurrence of calcite and to identify its sources. The mineralogy of the glacigenic Virttaankangas complex was studied using material from 21 sediment drill cores. Fine-grained calcite is present in trace amounts $(<<1.4 \%)$ in the glaciofluvial and glaciolacustrine depositional units of the Virttaankangas complex.The topmost littoral sands were practically devoid of calcite. The isotope records of carbon and oxygen, the angular morphology of the grains and the uniform dispersion of calcite in the complex suggest a clastic origin for calcite, with no evidence for in-situ precipitation. In order to constrain the source of calcite, the isotopic composition of carbon and oxygen in five calcite samples was compared to the isotopic data from five carbonate rock erratics and eight crystalline bedrock samples from the region. Based on carbon and oxygen isotope ratios and chemical compositions, the dispersed calcite grains of the Virttaankangas complex appear to have been derived from the Mesoproterozoic Satakunta Formation, some $30 \mathrm{~km}$ NW from the Virttaankangas area. In sandstone, calcite is predominantly present as diagenetic cement in grain interspaces, concretions and interlayers. The source of detrital calcite was unexpected, as prior to this study the Satakunta sandstone has not been known to contain calcite.
\end{abstract}

Key words: glaciofluvial features, sediments, calcite, isotope ratios, C- I3/C-I2, O- I 8/O- I6, provenance, sandstone, Virttaankangas, Finland

*Corresponding author email: nina.kortelainen@gtk.fi

\section{Introduction}

The glacigenic Virttaankangas complex consists of reddish sandy material predominantly eroded and transported from the Mesoproterozoic Satakunta sandstone during the last deglaciation (Kaitanen \& Ström, 1978). Groundwaters in the Virttaankangas aquifer are characterized by high $\mathrm{pH}$ values up to 9.5 (Kortelainen, 2005), which are exceptional for an unconsolidated aquifer composed of silicate minerals, such as potassium and sodium feldspars, quartz and micas. These high $\mathrm{pH}$ values have apparently been 
derived from reactions between the sediments and groundwater, but they are in strong contrast to the $\mathrm{pH}$ normally recorded in shallow groundwaters of the Fennoscandian shield, averaging 6.4 (Lahermo et al., 1990; Tarvainen et al., 2001). The Virttaankangas aquifer will be the site for long-term artificial groundwater recharge activities, supplying drinking water for the needs of the Turku region in SW Finland (Artimo et al., 2003). Understanding the origin of the unusual geochemistry of the Virttaankangas groundwaters is an important issue for constraining the operation of the future artificial groundwater plant.

In mineralogical studies, the Virttaankangas complex was observed to contain dispersed, fine-grained calcite. Reactions between dissolved $\mathrm{CO}_{2}$ and calcite have a high tendency to raise water $\mathrm{pH}$ (e.g. Drever, 1997; Appelo \& Postma, 1999), which may also explain the unusually high $\mathrm{pH}$ values recorded in the Virttaankangas aquifer (Kortelainen, 2005). The aim of this study is to determine the occurrence, dispersal and the source of carbonate minerals in the Virttaankangas sedimentary material.

Calcite could be present in the Virttaankangas sediments as an in-situ precipitate or as a detrital phase transported from the source area. In the light of the existing literature, the presence of detrital carbonate in the glacigenic sediments appears to be unlikely, as no obvious source for carbonate minerals is available in the Virttaankangas area. In addition, previous studies have not reported the presence of carbonate minerals in the Satakunta sandstone (Simonen $\&$ Kouvo, 1955; Marttila, 1969; Kohonen et al., 1993; Veräjämäki, 1998), although it is the principal source of sedimentary material in the Virttaankangas glacigenic complex (Kaitanen \& Ström, 1978). In the studies of Simonen \& Kouvo (1955) and Veräjämäki (1998) the Satakunta sandstone is described to mainly consist of quartz, K-feldspar, plagioclase and rock fragments in a matrix composed of quartz and micas. Typical accessory minerals include garnet, sillimanite, ilmenite, zircon, monazite and topaz.

The isotopic signatures of carbon and oxygen in sedimentary carbonate minerals are valuable tools for constraining the origin of carbonate. In the case of detrital calcite, the isotopic signatures can be used to constrain the source of the sedimentary material by direct comparison of the isotopic ratios. If calcite had been precipitated from local groundwaters, compositions near isotopic equilibrium with local groundwaters would be expected. In this study, the isotopic characteristics of calcite are used to provide evidence for the origin of dispersed calcite in the Virttaankangas complex.

\section{Geological setting}

The Virttaankangas complex belongs to the Säkylänharju-Virttaankangas glaciofluvial complex, which is a part of a large esker system in southwest Finland (Fig. 1). The Säkylänharju-Virttaankangas complex represents an interlobate esker deposition formed during the Late Weichselian and Early Holocene deglaciation of the Scandinavian Ice Sheet (Punkari, 1980; Kujansuu et al., 1995). The formation of the complex began ca. 11150 cal yr BP (Mäkinen, 2003), and it can be divided into three major depositional phases (Artimo et al., 2003). (I) The lowermost part of the esker formed as a result of repeated deposition of subaqueous fans in a subglacial tunnel, containing glaciofluvial sand and gravel. (II) During the second phase formed an interlobate ridge composed of sand and silt, and related glaciolacustrine deposits with silt and clay. (III) After deglaciation, regression of the former Baltic Sea, during the Yoldia Sea and the Ancylus Lake phases, activated intense littoral erosion of the glaciofluvial deposits forming the spit-platform and shore-zone sand deposits of the Virttaankangas plain (Mäkinen \& Räsänen, 2003). The Virttaankangas complex covers $80 \mathrm{~km}^{2}$ and the total thickness of unconsolidated sediments generally varies from 20 to $50 \mathrm{~m}$, but reaches $90 \mathrm{~m}$ locally in a bedrock fault zone.

The Säkylänharju-Virttaankangas complex has been deposited directly on the Paleoproterozoic (1900-1800 Ma) basement consisting mainly of plutonic quartz-diorite and tonalite (Salli, 1953). The southeast contact of the Mesoproterozoic Satakunta Formation is met approximately 10-15 $\mathrm{km} \mathrm{W}$ and NW from the Virttaankangas study area 


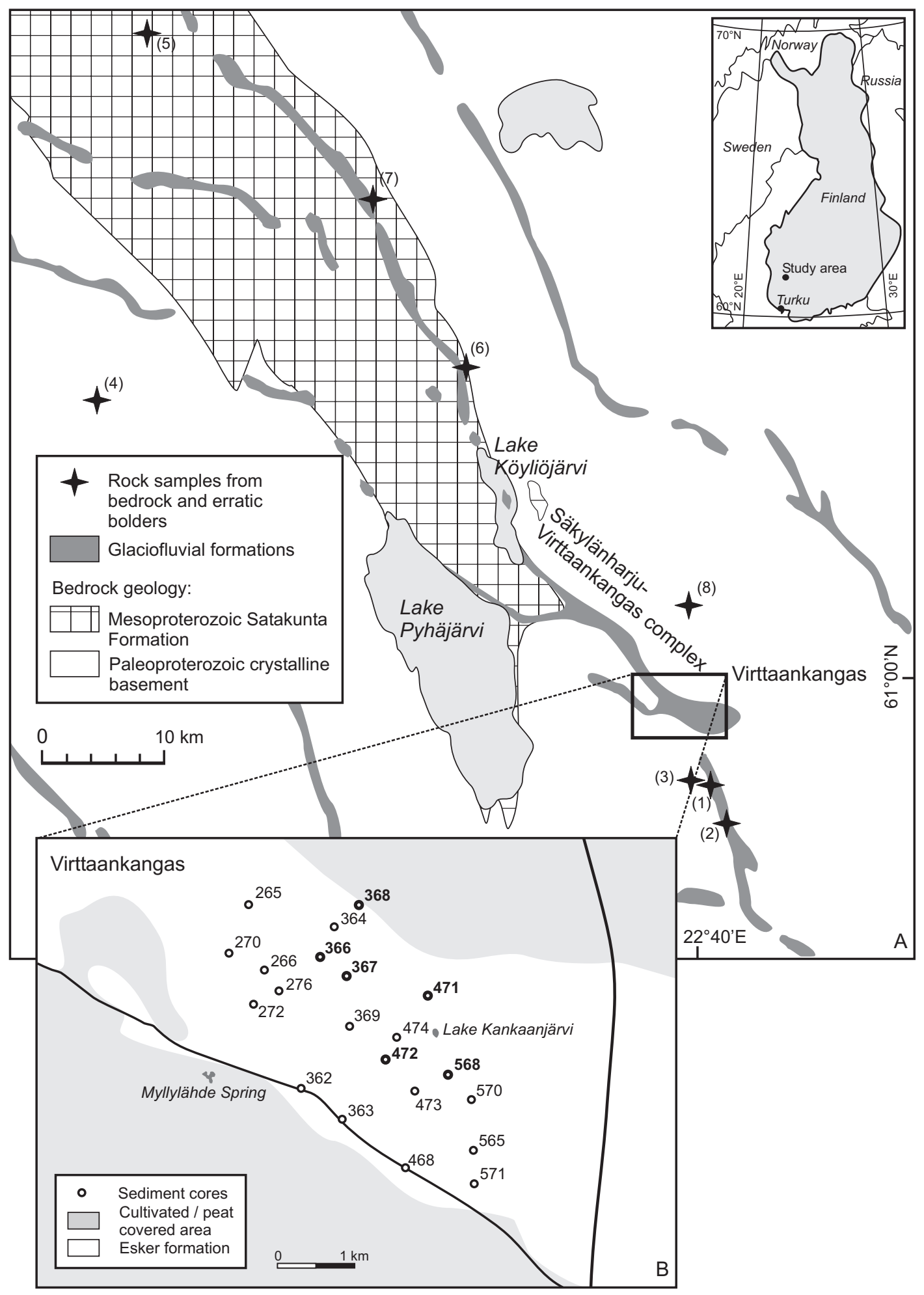

Fig. I. a) Location of the study area showing the sites of the erratics and bedrock drillings, b) Sediment drilling sites in the Virttaankangas area. Sample site codes are summarised in Table 2. 
(Fig. 1; Hämäläinen, 1994; Vorma \& Niemelä, 1994). The formation is composed of sandy and gravely sediments deposited in a graben structure (Simonen, 1980). The unmetamorphosed, poorly exposed sandstone follows a fault controlled NW-SE trend to the Gulf of Bothnia. The Satakunta sandstone is bounded by Svecofennian granitoids and supracrustal rocks in the east and the $1573 \pm 8 \mathrm{Ma}$ Laitila rapakivi granite batholith in the west (Vaasjoki, 1977; Vorma \& Niemelä, 1994). The rapakivi granite and the sandstone are cut by $1260 \pm 10 \mathrm{Ma}$ diabase dikes (Suominen, 1991), which is the minimum age of the Satakunta Formation. An estimated age of the sandstone is $1300-1400 \mathrm{Ma}$ (Simonen, 1980). The NW-SE trend of the sandstone basin runs parallel to the last main direction of the Weichselian ice flow as well as the location of interlobate subglacial meltwater tunnels on the Satakunta graben (Mäkinen, 2003). This combination has provided large amounts of easily eroded sandstone material to the Säkylänharju-Virttaankangas complex.

Only a few sedimentary carbonate rock occurrences are known from the surrounding region of the Säkylänharju-Virttaankangas complex. A Paleoproterozoic sedimentary marble unit is located in Vampula, $7 \mathrm{~km}$ to the north of Virttaankangas (Matisto, 1978; Karhu, 1993), and an Ordovician limestone succession is known to exist in the bottom of the Gulf of Bothnia, ca. $200 \mathrm{~km}$ to the NW (Winterhalter, 1972). One glacially transported boulder of Ordovician limestone has been met in the Virttaankangas area (Uutela, 1989). An early study by Laitakari (1925) noted the occurrence of minor carbonate bearing interlayes in the Satakunta sandstone, which have not been mentioned in more recent investigations (Simonen \& Kouvo, 1955; Marttila, 1969; Kohonen et al., 1993; Veräjämäki, 1998).

\section{Materials and methods}

In order to study the mineralogy of the Virttaankangas complex, 616 sediment samples representing 21 drill cores were investigated (Fig. 1). The samples were recovered from the sedimentary matter collect- ed during drilling of groundwater observation wells. Generally, 1 to $1.5 \mathrm{~m}$ of sediment core was sampled, containing 1 to $3 \mathrm{~kg}$ of dry sediment. The cores 366 , 367, 368, 471, 472 and 568 were selected for detailed mineralogical and isotope geochemical studies (Fig. 1). Isotopic analyses of calcite were carried out for 5 samples from cores 366, 367, 368 and 471.

Potential sources of carbonate in the sedimentary material were investigated by analyzing samples from erratics collected from the Virttaankangas region and bedrock samples taken from three archived drill cores of the Satakunta sandstone stored at the Loppi National Drill Core Depot (Fig. 1). Data were supplemented by results from an earlier survey by Karhu (1993).

The mineralogical composition, soil type, grain size and sorting of the sediment samples were investigated. XRD (X-ray diffraction) analyses ( $\mathrm{CuK} \alpha$ radiation, $\left.40 \mathrm{kV}, 55 \mathrm{~mA}, 2-70^{\circ} 2 \theta\right)$ were performed on 35 selected wet-screened samples $(<0.2 \mathrm{~mm}$ and $0.2-2.0 \mathrm{~mm}$ fractions). Two samples (sediment cores 366 and 367) with a high carbonate content were analyzed by SEM/EDS (scanning electron microscope/ energy dispersive spectrometer) and one sample (core 472) by an EPMA (electron probe micro analyser, $15 \mathrm{kV}, 10 \mathrm{nA}$, spot size $10 \mu \mathrm{m})$. Dry-screened sediment samples $(<0.25 \mathrm{~mm})$ were generally used for isotope analyses in order to prevent carbonate dissolution during sediment handling. The erratics and bedrock samples were studied micro- and macroscopically. Additionally, calcite from the bedrock cores M52PO-60-001 and TSV/OY-1F-82430-PT-13101 from the Satakunta sandstone were analyzed using EPMA. The mineralogical determinations were carried out in the Laboratory for Mineralogy at the Geological Survey of Finland (GTK), using Philips X'Pert MPD for XRD analyses, Cameca SX50 and Cameca SX100 for EPMA and Jeol-JSM-5900LV attached with Oxford Instruments EDS-analyser for SEM/EDS. The total amount of carbon in the sediment cores was determined from untreated subsamples using a carbon analyser (Leco) in order to obtain a rough estimate of carbonate contents in the cores. The total carbon analyses were conducted in the Geolaboratory, at GTK. 
Prior to isotopic analysis of carbonate samples, the carbonate mineral in question was identified and roughly quantified by XRD analysis. The same procedure was followed both for sediment $(<0.25 \mathrm{~mm})$, erratic and bedrock samples. For the determination of $\delta^{13} \mathrm{C}$ and $\delta^{18} \mathrm{O}$ in calcite, the sample was reacted with supersaturated phosphoric acid. To ensure a complete reaction, the sample vessels were kept in a water bath at $50{ }^{\circ} \mathrm{C}$ for 2 hours. The evolved $\mathrm{CO}_{2}$ was removed from the vessels by vacuum extraction and cryogenic collection. Isotopic ratios of $\mathrm{CO}_{2}$ were measured by a Finnigan MAT 251 gas source mass spectrometer at GTK. Isotopic ratios are reported using the $\delta$ notation as a per mil (\%o) difference relative to the international Vienna Standard Mean Ocean Water (VSMOW) standard for oxygen and the Vienna Peedee Belemnite (VPDB) standard for carbon. The $\delta$-value is defined as

$$
\delta=\left(\mathrm{R}_{\text {sample }} / \mathrm{R}_{\text {standard }}-1\right) \times 1000,
$$

where $\mathrm{R}$ is the ${ }^{18} \mathrm{O} /{ }^{16} \mathrm{O}$ or ${ }^{13} \mathrm{C} /{ }^{12} \mathrm{C}$ ratio of the sample or standard and $\delta$ is $\delta^{18} \mathrm{O}$ or $\delta^{13} \mathrm{C}$. The repeatability of analyses was $\leq 0.05 \%$ o for oxygen and carbon in calcite.

\section{Results}

\section{I.Virttaankangas sediments}

The 2.0 to $0.2 \mathrm{~mm}$ and $<0.2 \mathrm{~mm}$ size fractions of Virttaankangas sediments mainly consist of quartz, microcline, plagioclase and hematite. Estimated by microscopic studies and XRD analyses, the quartz content in the 2.0 to $0.2 \mathrm{~mm}$ fraction is typically 50 to $75 \%$, and in the $<0.2 \mathrm{~mm}$ fraction 25 to $45 \%$. The quantities of microcline and plagioclase vary in both fractions within 15 to $25 \%$. Hematite occurs very commonly in all samples, amounting to $1-10 \%$ in the 2.0 to $0.2 \mathrm{~mm}$ fraction and to $10-40 \%$ in the $<0.2 \mathrm{~mm}$ fraction. Mica, chlorite, amphibole, calcite and talc are present as accessory minerals.

Calcite was observed to be commonly present in the $<0.2 \mathrm{~mm}$ fraction, and occasionally also in the 2.0 to $0.2 \mathrm{~mm}$ fraction. According to XRD analyses, the highest content of calcite in the fine fraction was 3.7 to 5 weight per cent (wt.\%), which corresponds to 0.5 to $1.4 \mathrm{wt} . \%$ of calcite in the total sediment. The carbonate grains are about $0.1 \mathrm{~mm}$ in diameter with sharp and angular forms (Fig. 2). Based on 35 microprobe analyses (core 472), the carbonate

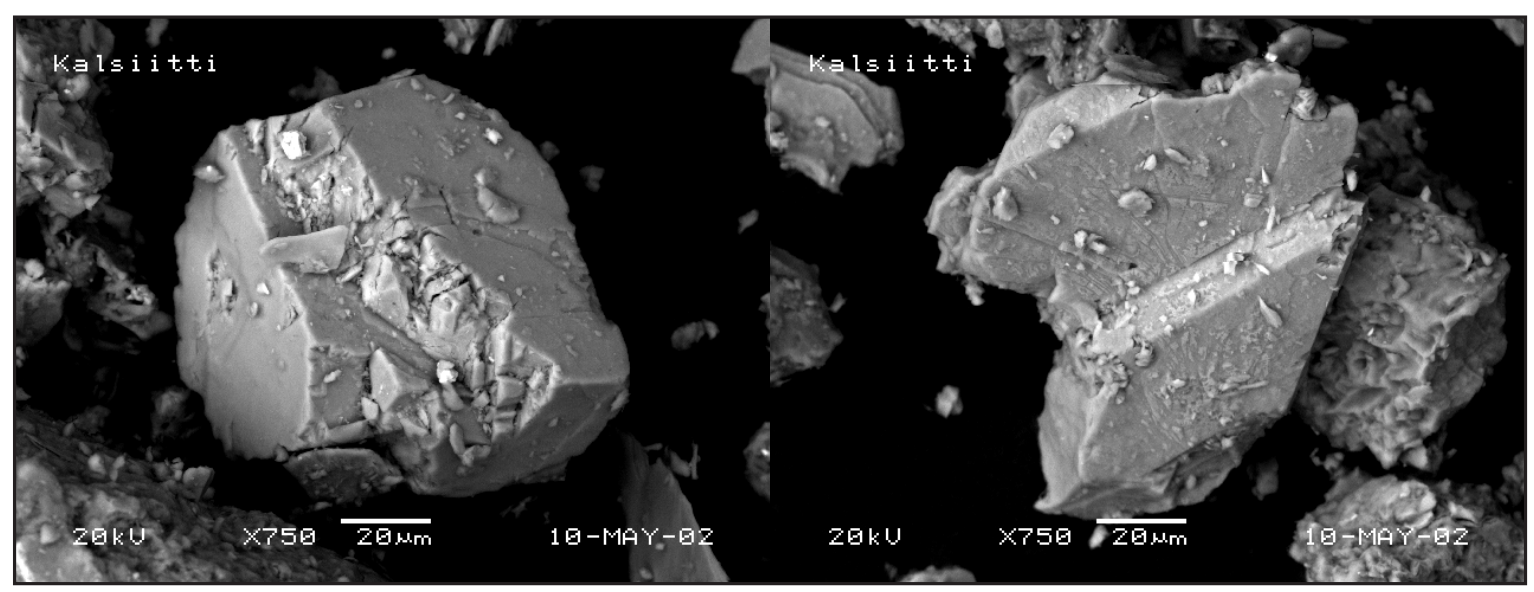

Fig. 2. Backscattered electron (BSE) images of clastic calcite grains from the Virttaankangas sediments (sample 367/22-23). 
Table I. Elemental composition of calcite from the Virttaankangas complex and the Satakunta Formation.

\begin{tabular}{|c|c|c|c|c|c|c|c|c|c|c|}
\hline $\begin{array}{l}\text { Map } \\
\text { index }\end{array}$ & Sample & Sample type & $\begin{array}{l}\mathrm{CaO} \\
\text { wt. } \%\end{array}$ & $\begin{array}{l}\mathrm{MgO} \\
\text { wt. } \%\end{array}$ & $\begin{array}{l}\mathrm{FeO} \\
\text { wt.\% }\end{array}$ & $\begin{array}{l}\mathrm{MnO} \\
\text { wt. } \%\end{array}$ & $\begin{array}{l}\mathrm{SrO} \\
\text { wt.\% }\end{array}$ & $\begin{array}{l}\mathrm{CO}_{2}{ }^{\mathrm{a}} \\
\text { wt. } \%\end{array}$ & $\begin{array}{l}\text { Total } \\
\text { wt.\% }\end{array}$ & $n^{b}$ \\
\hline 472 & $\begin{array}{l}472 / 28.5-30.0 \mathrm{~m} \text { (fraction } \\
0.063-0.2 \mathrm{~mm})\end{array}$ & $\begin{array}{l}\text { Sediment } \\
\text { calcite }\end{array}$ & 54.69 & 0.02 & 0.01 & 0.21 & b.d.l. ${ }^{\mathrm{c}}$ & 43.16 & 98.10 & 35 \\
\hline (5) & M52-PO -60-001 / $328 \mathrm{~m}$ & $\begin{array}{l}\text { Sandstone } \\
\text { calcite }\end{array}$ & 55.86 & 0.09 & b.d.l. & 0.23 & b.d.l. & 42.68 & 98.86 & 10 \\
\hline (6) & $\begin{array}{l}\text { TSV/OY-1F-82430-PT- } \\
13101 / 159 \mathrm{~m}\end{array}$ & $\begin{array}{l}\text { Sandstone } \\
\text { calcite }\end{array}$ & 56.22 & b.d.l. & b.d.l. & 0.07 & b.d.l. & 42.57 & 98.86 & 10 \\
\hline
\end{tabular}

a) Calculated based on stoichiometry; ${ }^{\text {b) }} \mathrm{n}$ = number of analyses; ${ }^{\mathrm{c})}$ b.d.l. = below detection limit.

is practically stoichiometric calcite $\left(\mathrm{CaCO}_{3}\right)$. The average major and trace element composition of the calcite is given in Table 1.

Calcite was observed to occur predominantly in glaciofluvial and glaciolacustrine sediments formed during first two depositional phases, and its presence is independent of the level of the groundwater table. The littoral sands, representing the last depositional phase, are almost completely devoid of carbonate minerals. Excluding a few outliers, the total carbon content $\left(\mathrm{C}_{\text {tot }}\right)$ of the Virttaankangas sediments varied from 0 to 0.15 wt. $\%$, which corresponds to 0 to 1.25 wt. $\%$ of calcite, assuming no contribution of carbon from organic sources. This agrees with the XRD analysis. Approximately one metre thick organic soil layer was observed on the top in most drill cores. The occurrence of calcite, expressed as $\mathrm{C}_{\text {tot }}$, in comparison of sediment stratigraphy in two drill cores of 367 and 568, is illustrated in Figure 3.

The isotopic ratios of carbon and oxygen in calcite from five sediment core samples from the Virttaankangas complex are presented in Table 2. The $\delta^{13} \mathrm{C}$ and $\delta^{18} \mathrm{O}$ values of calcite varied from -5.67 to $-4.45 \%$ (VPDB) and from 23.20 to $23.53 \%$ (VSMOW), respectively.

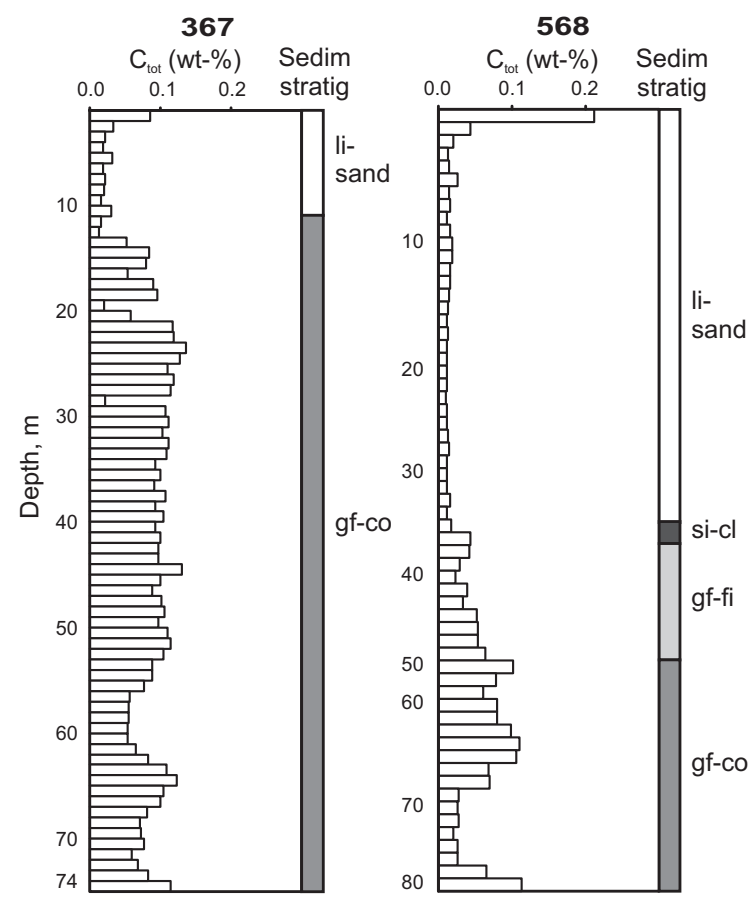

Fig. 3. $C_{\text {tot }}$ measured from sediment cores 367 and 568 . The corresponding sediment stratigraphy according to a three-dimensional geologic model by Artimo et al. (2003) is shown on the left side of each column; glaciofluvial coarse sediment (gf-co), glaciofluvial fine (gf-fi), silt and clay (si-cl), littoral sand (li-sand). 


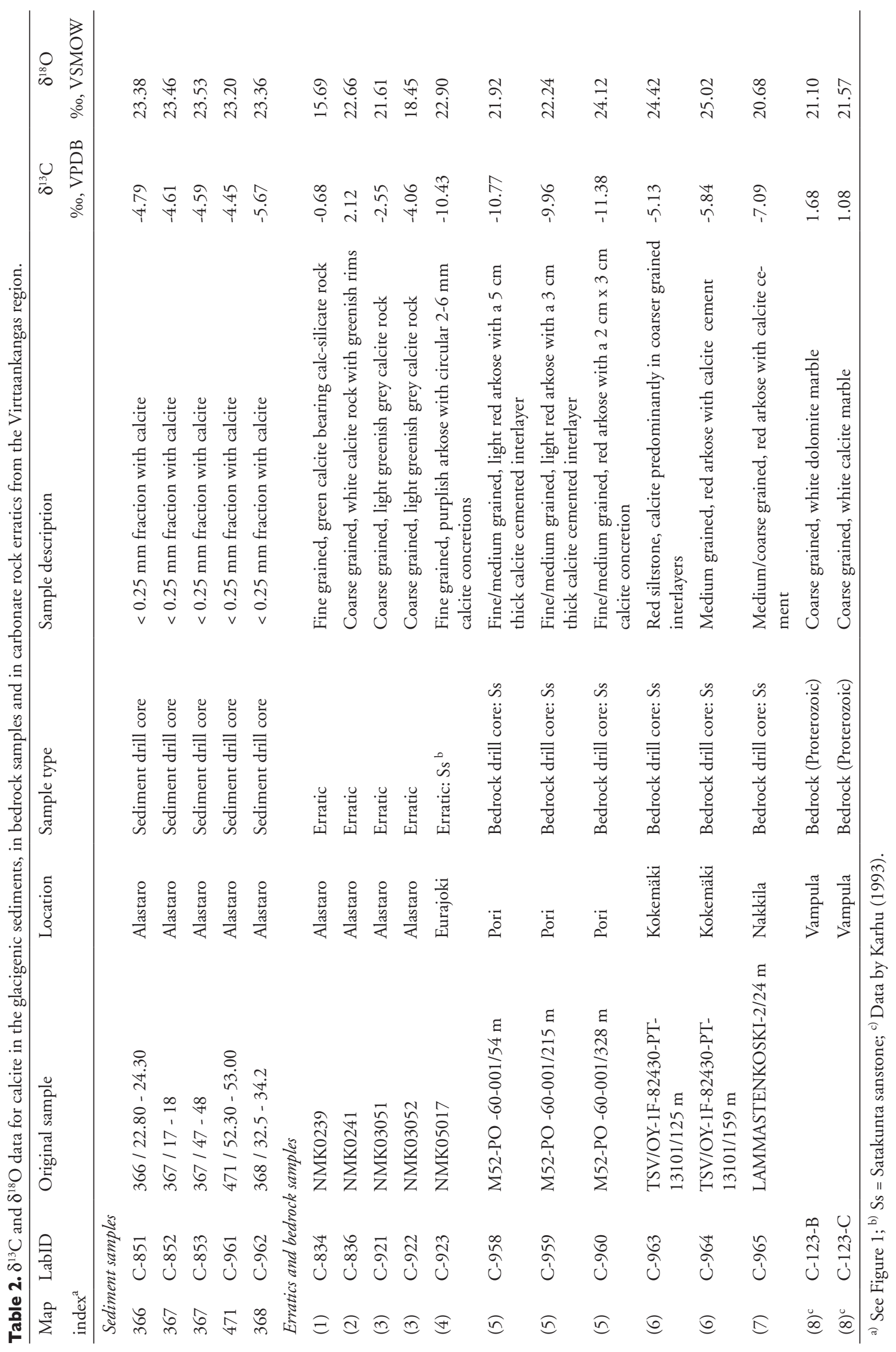




\subsection{Carbonate bearing erratic and bedrock samples}

The isotopic composition of carbon and oxygen in various carbonate rock occurrences was studied in order to constrain the origin of dispersed calcite in the Virttaankangas complex. The sample descriptions and the $\delta^{13} \mathrm{C}$ and $\delta^{18} \mathrm{O}$ values of calcite in erratic boulders and drill core samples are given in Table 2 . The carbonate rock erratics recorded $\delta^{13} \mathrm{C}$ values ranging from $-4.06 \%$ to $+2.12 \%$ and $\delta^{18} \mathrm{O}$ values from $18.45 \%$ to $22.66 \%$. For this study, all Satakunta sandstone drill cores available $(\mathrm{n}=16)$ were restudied. In total, 13 out of the 16 cores were observed to contain carbonate. In most drill cores, traces of carbonate minerals occurred in hematite rich interlayers. Three drill cores and one Satakunta sandstone erratic revealed locally occurring notable amounts of fine to medium grained calcite (Table 2). Calcite spar was present predominantly as cement in grain interspaces, concretions and interlayers (Fig. 4). It is characterized by poikilotopic texture, where optically equal oriented mono- or polycrystalline calcite spar encloses several clastic grains. Six samples from the drill cores and one from the erratic boulder yielded $\delta^{13} \mathrm{C}$ values varying from $-11.38 \%$ to $-5.13 \%$ and $\delta^{18} \mathrm{O}$ values from $20.68 \%$ to $25.02 \%$ (Table 2). The average major and trace element composition of calcite in the drill cores M52-PO-60-001 and TSV/OY-1F-82430-PT13101 is summarized in Table 1.

\section{Discussion}

Prior to this study the only indication of carbonatebearing aquifer material in the Virttaankangas complex was the high $\mathrm{pH}$ recorded in groundwater samples (Kortelainen, 2005). The mineralogical investigations revealed that the Virttaankangas sediments (mainly the $<0.2 \mathrm{~mm}$ fraction) contain very finegrained calcite as an accessory mineral. The content of calcite is generally $\ll 1.4 \mathrm{wt} . \%$, and it is fairly

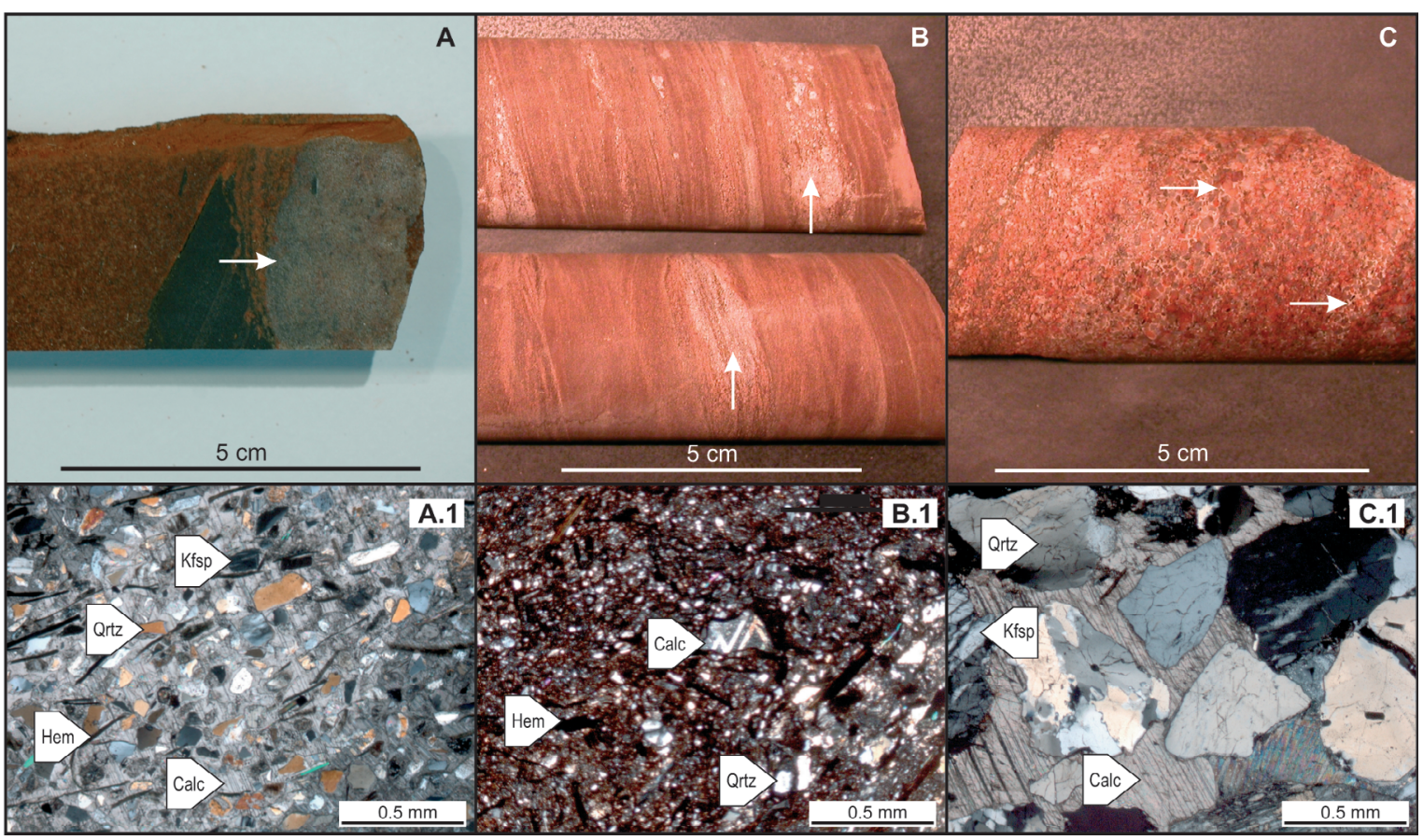

Fig. 4. Macroscopic and thin section images (crossed polarizers) of calcite bearing samples from the Satakunta sandstone: A and A.I: site (5), sample C-960; B and B.I: site (6), sample C-963; C and C.I: site (6), sample C-964 (Fig. I; Table 2). 
evenly distributed in the glaciofluvial and glaciolacustrine depositional units. The uppermost littoral sands are practically devoid of calcite. This unit was formed when shoreline forces re-deposited sediments in an interlobate ridge and related sedimentary units. Presumably, calcite under these conditions was dissolved in undersaturated waters of the former Baltic Sea.

The $\delta^{18} \mathrm{O}$ and $\delta^{13} \mathrm{C}$ values of the Virttaankangas dispersed calcite were compared with those resulting from precipitation in modern conditions. The calcite in the aquifer sediments had a $\delta^{13} \mathrm{C}$ value of -4.8 $\pm 0.5 \%$ and a $\delta^{18} \mathrm{O}$ value of $23.4 \pm 0.1 \%$ (Fig. 5). The fractionation of oxygen between calcite and local groundwater is dependent on the temperature of calcite precipitation (O’Neil et al., 1969; Friedman $\&$ O’Neil, 1977). The present mean surface temperature of $5 \pm 2{ }^{\circ} \mathrm{C}$ and the $\delta^{18} \mathrm{O}$ value of $-12.5 \%$ for the modern groundwater (Kortelainen, 2005) lead to calcite with a $\delta^{18} \mathrm{O}$ value of $20.6 \pm 0.5 \%$. This value is significantly lower than those measured for dis- persed calcite in the Virttaankangas complex. At conditions, where calcite might precipitate, the fractionation of carbon isotopes between calcite and dissolved inorganic carbon is only few per mils, and the $\delta^{13} \mathrm{C}$ in precipitated calcite will closely follow that in dissolved inorganic carbon in groundwater. The $\delta^{13} \mathrm{C}_{\mathrm{DIC}}$ values of Virttaankangas groundwaters vary from $-24 \%$ to $-13 \%$ o (Kortelainen, 2005), and therefore, the present-day groundwaters can not precipitate calcite with a $\delta^{13} \mathrm{C}$ value of $-4.8 \pm 0.5 \%$. The isotope data, the angular morphology of the calcite grains (Fig. 2) and the uniform dispersion of calcite in the complex strongly suggest an allochtonous, clastic origin for calcite in the Virttaankangas glacigenic complex.

The presence of detrital calcite in the glacigenic sediments was unexpected, as no obvious source of carbonate minerals was available in the area. The $\delta^{13} \mathrm{C}$ and $\delta^{18} \mathrm{O}$ values in carbonate rock erratics, possibly representing Precambrian marbles and vein calcite,

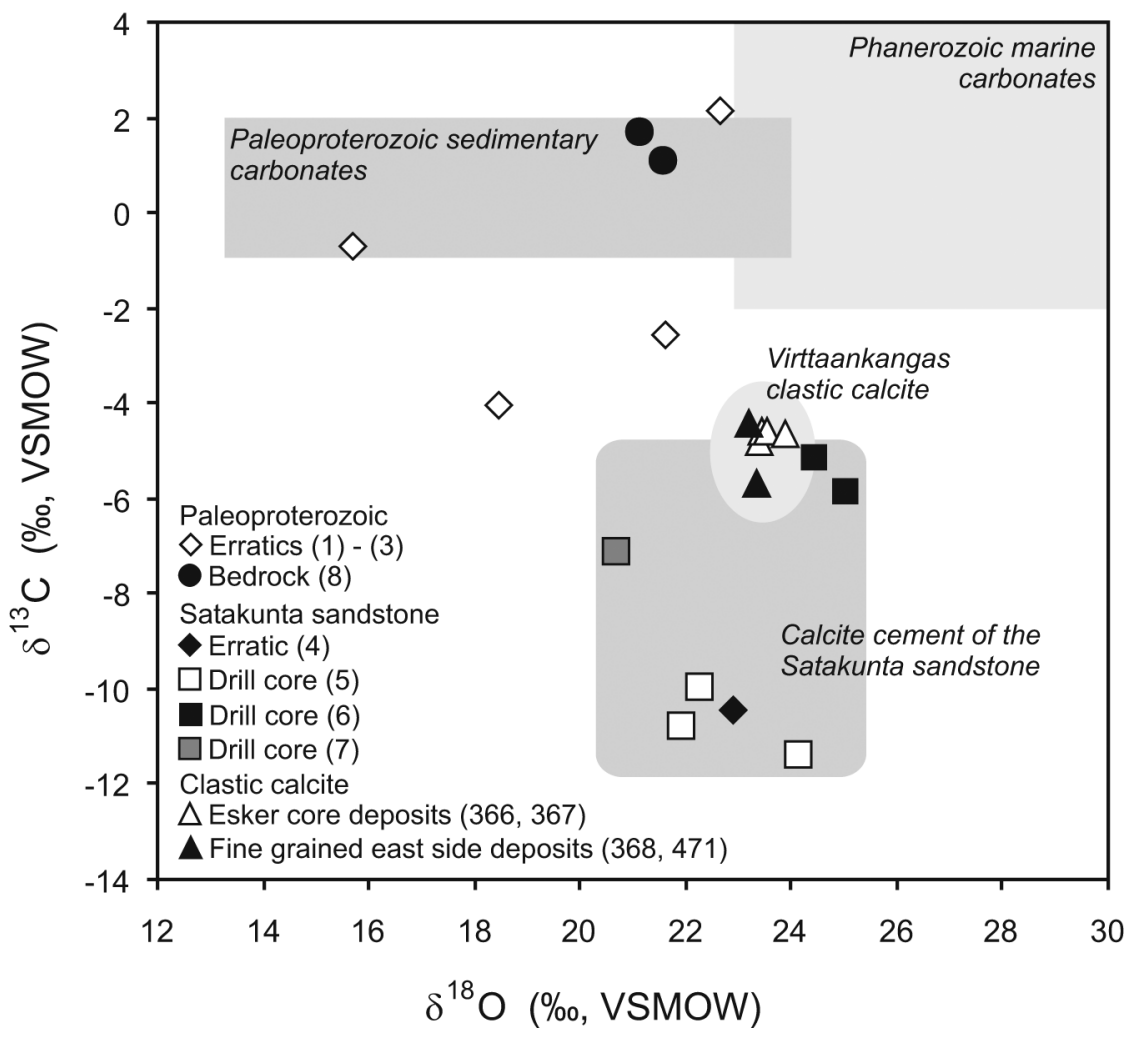

Fig. 5. Isotopic composition of carbon and oxygen in calcite from the Virttaankangas sediment cores (open triangles: cores 366, 367; filled triangles: cores 47I, 368) and in the calcite-bearing bedrock samples and erratics (for site numbers see Table 2). The fields for Paleoproterozoic and Phanerozoic sedimentary carbonates are based on results reported by Karhu (1993) and Veizer et al. (1999), respectively. 
excluded them from the list of possible sources of detrital calcite (Fig. 5). The reported isotopic characteristics of the Paleoproterozoic Vampula marble (Table 2) are also clearly outside the field for clastic calcite (Figs. 1, 5). One Ordovician limestone erratic boulder has been reported from the Virttaankangas area by Uutela (1989). Due to the lack of local Ordovician sample material, a general variation space for the Phanerozoic marine carbonates by Veizer et al. (1999) is illustrated in Figure 5. The $\delta^{13} \mathrm{C}$ and $\delta^{18} \mathrm{O}$ values of calcite in the Virttaankangas complex clearly differ from those of Phanerozoic marine carbonates.

The Satakunta sandstone is generally composed of $45-60 \%$ quartz, $16-26 \%$ K-feldspar (microcline), $<5 \%$ plagioclase, $<2 \%$ rock fragments, ca. $1 \%$ accessories and $16-30 \%$ matrix (Simonen \& Kouvo, 1955; Veräjämäki, 1998). The Satakunta sandstone may be a potential source of calcite, but only one brief notice of 1 to $5 \mathrm{~cm}$ thick, impure limestone interlayers in erratic boulders has been reported in the literature (Laitakari, 1925). In the Satakunta sandstone drill cores a significant amount of calcite was located in three cores, representing diagenetic calcite cement (Fig. 4). These three most calcite rich drill cores were further studied. Notable variation was recorded between the separate drill cores, especially in the isotopic composition of carbon and oxygen in sandstone calcites (Table 2; Fig. 5). In the SE corner of the sandstone formation the $\delta^{18} \mathrm{O}$ and $\delta^{13} \mathrm{C}$ values were more tightly constrained from -5.84 to $-5.13 \%$ and from 24.43 to $25.02 \%$, respectively. These isotope values compare well with those measured from calcites of the Virttaankangas complex. Accordingly, the source of calcite appears to be located in the Satakunta Formation. More specifically, the source might be located in the SE corner of the unit, approximately $30 \mathrm{~km}$ to the northwest of the Virttaankangas complex (Fig. 1).

\section{Conclusions}

The following conclusions can be drawn from the study:

1) Trace amounts of calcite are dispersed in the glaciofluvial and glaciolacustrine sediments of the Virttaankangas complex. The littoral sands of the last depositional phase are practically devoid of calcite.

2) The isotope records of oxygen and carbon, the morphology of the calcite grains and the uniform dispersion of calcite in the complex suggest a clastic origin for the dispersed calcite grains in the Virttaankangas complex, with no evidence for insitu precipitation.

3) Based on $\delta^{13} \mathrm{C}$ and $\delta^{18} \mathrm{O}$ values and elemental compositions, the dispersed calcite of the Virttaankangas complex has been derived from diagenetic calcite locally abundantly present in the Mesoproterozoic Satakunta sandstone, some 30 $\mathrm{km} \mathrm{NW}$ of the Virttaankangas area.

4) The results vindicate the earlier suggestion that the Satakunta Formation is the main source of clastic material in the Virttaankangas complex.

\section{Acknowledgements}

The study was supported by Turku Region Water Ltd. and the Geological Survey of Finland. The personnel in the Laboratory for Isotope Geology and the Laboratory for Mineralogy at the Geological Survey of Finland are thanked for their contribution to the study. We also thank E. Versh, J. Kohonen and A. Heinsalu for constructive and useful comments. 


\section{References}

Appelo, C.A.J. \& Postma, D., 1999. Geochemistry, Groundwater and Pollution, $4^{\text {th }}$ Edition. A.A. Balkema, Rotterdam, $536 \mathrm{p}$.

Artimo, A., Mäkinen, J., Berg, R.C., Abert, C.C. \& Salonen, V.-P., 2003. Three-dimensional geologic modeling and visualization of the Virttaankangas aquifer, southwestern Finland. Hydrogeology Journal 11, 378-386.

Drever, J.I., 1997. The Geochemistry of Natural Waters, $3^{\text {rd }}$ edition. Prentice-Hall, Upper Saddle River (N.J.), $436 \mathrm{p}$.

Friedman, I. \& O'Neil, J.R., 1977. Compilation of stable isotope fractionation factors of geochemical interest. In: Fleischer, M. (ed.) Data of Geochemistry, $6^{\text {th }}$ edition. U.S. Geological Survey Professional Paper, 440$\mathrm{KK}, 12 \mathrm{p}$.

Hämäläinen, A., 1994. Kokemäki. Geological map of Finland 1:100 000, pre-Quaternary rocks, sheet 1134, Geological Survey of Finland.

Kaitanen, V. \& Ström, O., 1978. Shape development of sandstone cobbles associated with the Säkylä-Mellilä esker, southwest Finland. Fennia 155, 23-67.

Karhu, J.A., 1993. Paleoproterozoic evolution of the carbon isotope ratios of sedimentary carbonates in the Fennoscandian Shield. Geological Survey of Finland, Bulletin $371,87 \mathrm{p}$.

Kohonen, J., Pihlaja, P., Kujala, H. \& Marmo, J., 1993. Sedimentation of the Jotnian Satakunta sandstone, western Finland. Geological Survey of Finland, Bulletin 369, $35 \mathrm{p}$.

Kortelainen, N., 2005. Use of isotopes in planning of an artificial groundwater recharge plant: Virttaankangas aquifer in SW Finland. In: Buzek, F. \& Novák, M. (eds.) $6^{\text {th }}$ International Symposium on Applied Isotope Geochemistry, Prague, Czech Republic, September 11-16, 2005, Abstracts. Prague, Czech Geological Survey, pp. 122-123.

Kujansuu, R., Kurkinen, I. \& Niemelä, J., 1995. Glaciofluvial deposits in Finland. In: Ehlers, J., Kozarski, S. \& Gibbard, P. (eds.) Glacial Deposits in North-East Europe. A.A. Balkema, Rotterdam, pp. 67-75.

Laitakari, A., 1925. Über das jotnische Gebiet von Satakunta. Bulletin de la Commission Géologique de Finlande 73, $43 \mathrm{p}$.

Lahermo, P., Ilmasti, M., Juntunen, R. \& Taka, M., 1990. The Geochemical Atlas of Finland, Part 1. Geological Survey of Finland, Espoo, 66 p.

Marttila, E., 1969. Satakunnan hiekkakiven sedimentaatioolosuhteista. Ph.Lic. Thesis, University of Turku, Finland, $157 \mathrm{p}$.

Matisto, A., 1978. Huittinen. Explanation to the Geological map of Finland 1:100 000, pre-Quaternary rocks, sheet 2112, Geological Survey of Finland, 30 p. (in Finnish with English summary).

Mäkinen, J., 2003. The development of depositional environment within the interlobate Säkylänharju-Virt- taankangas glaciofluvial complex in SW Finland. Annales Academiae Scientiarum Fennicae, Geologica-Geographica 165, $65 \mathrm{p}$.

Mäkinen, J., Räsänen, M., 2003. Early Holocene regressive spit-platform and nearshore sedimentation on a glaciofluvial complex during the Yoldia Sea and the Ancylus Lake phases of the Baltic Basin, SW Finland. Sedimentary Geology 158, 25-56.

O’Neil, J., Clayton, R. \& Mayeda, T., 1969. Oxygen isotope fractionation in divalent metal carbonates. Journal of Chemical Physics 15, 5547-5558.

Punkari, M., 1980. The ice lobes of the Scandinavian ice sheet during the deglaciation in Finland. Boreas 9, 307-310.

Salli, I., 1953. Loimaa. Geological map of Finland 1:100000, pre-Quaternary rocks, sheet 2111, Geological Survey of Finland.

Simonen, A. \& Kouvo, O., 1955. Sandstones in Finland. Bulletin de la Commission Géologique de Finlande 168, 57-87.

Simonen, A., 1980. The Precambrian in Finland. Geological Survey of Finland, Bulletin 304, 58 p.

Suominen, V., 1991. The chronostratigraphy of southwestern Finland, with special reference to Postjotnian diabases. Geological Survey of Finland, Bulletin 356, 100 p.

Tarvainen, T., Lahermo, P., Hatakka, T., Huikuri, P., Ilmasti, M., Juntunen, R., Karhu, J., Kortelainen, N., Nikkarinen, M. \& Väisänen, U., 2001. Chemical composition of well water in Finland - main results of the "one thousand wells" project. In: Autio, S. (ed.) Geological Survey of Finland, Current Research 1999-2000. Geological Survey of Finland, Special Paper 31, 57-76.

Uutela, A., 1989. Age and dispersal of sedimentary erratics on the coast of southwestern Finland. Geological Survey of Finland, Bulletin 349, 100 p.

Vaasjoki, M., 1977. Rapakivi granites and other postorogenic rocks in Finland: their age and the lead isotopic composition of certain associated galena mineralizations. Geological Survey of Finland, Bulletin 294, 64 p.

Veizer, J., Ala, D., Azmy, K., Bruckschen, P., Buhl, D., Bruhn, F., Carden, G.A.F., Diener, A., Ebneth, S., Godderis, Y., Jasper, T., Korte, C., Pawellek, F., Podlaha, O.G. \& Strauss, H., $1999 .{ }^{87} \mathrm{Sr} /{ }^{86} \mathrm{Sr},{ }^{13} \mathrm{C}$, and ${ }^{18} \mathrm{O}$ evolution of Phanerozoic seawater. Chemical Geology 161, 59-88.

Veräjämäki, A., 1998. Kokemäki. Explanation to the Geological map of Finland 1:100 000, pre-Quaternary rocks, sheet 1134, Geological Survey of Finland, 51 p. (in Finnish with English summary).

Vorma, A. \& Niemelä, R., 1994. Yläne. Geological map of Finland 1:100 000, pre-Quaternary rocks, sheet 1133, Geological Survey of Finland.

Winterhalter, B., 1972. On the geology of the Bothnian Sea, an apeiric sea that has undergone Pleistocene glaciation. Geological Survey of Finland, Bulletin 258, 66 p. 